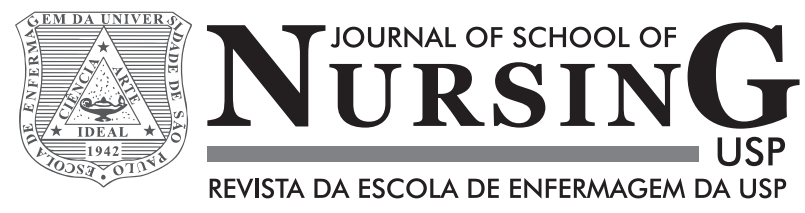

\title{
Managerial nursing competencies in the expansion of the Family Health Strategy*
}

\section{Competências gerenciais dos enfermeiros na ampliação da Estratégia Saúde da Família \\ Competencias de gestión de los enfermeros en la ampliación de la Estrategia Salud de la Familia}

\author{
Ingrid Margareth Voth Lowen ${ }^{1,2}$, Aida Maris Peres ${ }^{3}$, Karla Crozeta ${ }^{3}$, Elizabeth Bernardino ${ }^{3}$, Carmem Lúcia Colomé Beck
}

\footnotetext{
* Extracted from the dissertation "Competências gerenciais dos enfermeiros na ampliação da Estratégia Saúde da Família,” Programa de Pós-Graduação em Enfermagem, Universidade Federal do Paraná, 2014.

${ }^{1}$ Universidade Federal do Paraná, Programa de Pós-Graduação em Enfermagem, Curitiba, PR, Brazil.

${ }^{2}$ Secretaria Municipal de Saúde de Curitiba, Departamento de Atenção Primária, Curitiba, PR, Brazil.

${ }^{3}$ Universidade Federal do Paraná, Departamento de Enfermagem, Curitiba, PR, Brazil.

${ }^{4}$ Universidade Federal de Santa Maria, Santa Maria, RS, Brazil.
}

\section{ABSTRACT}

Objective: To relate the managerial competencies required of nurses with the process of change experienced in the expansion of the Family Health Strategy (FHS). Method: A qualitative research conducted in primary health care in a southern Brazilian city, through interviews with 32 managerial and clinical nurses. The interviews were processed by IRAMUTEQ software. The resulting classes were examined under five managerial competencies to promote change. Results: The four classes obtained from data were: the Family Health Strategy expansion process; confrontations and potentialities; mobilization for the change; innovations in medical and nursing consultations. The classes were related to one or more competencies. Conclusion: The expansion of the Family Health Strategy requires managerial competencies of implementing and sustaining change, negotiating agreements and commitments, using power and influence ethically and effectively, sponsoring and selling new ideas, and encouraging and promoting innovation.

\section{DESCRIPTORS}

Nursing; Primary Health Care; Family Health Strategy; Professional Competence; Practice Management. 


\section{INTRODUCTION}

In Brazil, the Primary Health Care (PHC) results from the construction and experience of the group of actors involved, including: users, social movements, workers and managers. It is considered the main gateway to the health system, it coordinates and integrates the various services and offers attention focused on the individual/ family and for most health conditions. The Family Health Strategy (FHS) is used to organize the PHC and has had a positive effect in improving the health conditions of the population, although it is still under construction and expansion. The organization of $\mathrm{PHC}$ with the expansion of family health teams requires structural and organizational changes. In addition to the existence of a minimal multidisciplinary team, a defined territory and other specificities, the FHS in practice should reaffirm the principles of universality, accessibility, bond, continuity of care, comprehensiveness, accountability, humanization, equity and social participation ${ }^{(1-2)}$.

To strengthen PHC in the municipality studied, the administration proposed significantly expanding the $\mathrm{FHS}^{(3)}$. This process of change requires professionals involved in the various administrative divisions to have management competency in planning and execution. The expansion included the restructuring of Health Units $(\mathrm{HU})$ being called traditional because they are not made up of family health teams, the reorganization of health teams (with the inclusion for the minimum teams of family health) and of the work process, the territorialization of each team's coverage area and strengthening the role of healthcare professionals ${ }^{(1)}$.

Nurses must be qualified to integrate and actively promote the principles of the current healthcare system, especially in interactive and managerial activities, which require involvement, organization and commitment to the needs of the population ${ }^{(4)}$. Therefore, in their managerial performances, for example in the expansion of family health teams, these professionals play a fundamental role in changing the structure and the work process from the mobilization of managerial competencies in their practice.

Competence is the behavioral ability to act appropriately, by using previously acquired knowledge. The theoretical framework that supports this study suggests that the necessary managerial competencies "should promote change in the organization and encouragement of adaptability"(5) by using the open system management model, based on contingency theory, with emphasis on political adaptation, creative problem solving, innovation and change management ${ }^{(5)}$.

In accordance with the chosen theoretical framework, changes represented in this scenario for the expansion of the FHS point toward the redefinition of the health team working process from a comprehensive care perspective focusing on families and care production, given the sociopolitical context that influences this process. Added to this fact, a gap in the production of knowledge was found regarding change processes in $\mathrm{PHC}$ and the necessary competencies for its management.

Considering the $\mathrm{PCH}$ context of the municipality studied, a scenario influenced by adversity was identified as being limited financial resources for the expansion of family health teams, restrictions on access to health services and their resolution; but also possibilities, among them being the physical structure of most HUs, and the managerial capacity and policy organization of health care. Therefore, the objective of this study was to relate nursing managerial competencies (required of nurses) with the process of change experienced in the Family Health Strategy expansion.

\section{METHOD}

A qualitative study employing a descriptive and exploratory approach, carried out in a municipality in southern Brazil. Of the eight HUs that had implemented FHS in six health districts (DS) in the first half of 2013, one HU was selected from each DS which had nurses on its staff who met the following inclusion criteria: nurses of both genders, who were working on the expansion of the FHS in the first half of 2013 and remained in office until the data collection. Nurses were excluded if they were away due to vacation, leave entitlements or health treatment during the data collection period.

Research participants were 32 nurses working in PHC, involved in the process; 16 nurses inserted in the family health teams and 16 nurses in management positions of these HU, of the DS and other departments that participated in the expansion of the FHS. Clinical nurses were referred to as "assist." and management nurses as "gest."

Data collection took place between January to April 2014, through on site interviews with a partially structured questionnaire and nurses on their work shift. Each interview took an average of 25 minutes and ethical aspects of confidentiality and coding of the participants were respected.

After characterizing the participants by age, place of work, training time, experience with FHS operations in the current position and professional qualification, the study sought to understand the process of change in the expansion of the FHS, identifying its facilitating and inhibiting factors, aspects related to communication, innovative practices and negotiation experienced by nurses and/ or the team working in different functions, management and assistance in order to relate the process of change to the management competencies described in the theoretical framework adopted in this study ${ }^{(5)}$. Thus, the five managerial competencies related to the change process which were used as reference for data analysis are: using power and influence ethically and effectively, sponsoring and selling new ideas, encouraging and promoting innovation, negotiating agreements and commitments, and implementing and sustaining change.

To support the analysis of qualitative research data, the IRAMUTEQ software (Interface de R pour les Analyses Multidimensionnelles de Textes et de Questionnaires) was 
used. This program is free and anchored to software $\mathrm{R}$, enabling different processing and statistical analysis of produced texts. It was developed in 2009 by Pierre Ratinaud in French, and currently has complete dictionaries in other languages. Its use began in Brazil in 2013 and enables accurate analysis ${ }^{(6-7)}$, configuring as an innovation for qualitative health research. For data processing, the Descending Hierarchical Classification (DHC) method was used.

From the corpus, the dimensioning of the text segments or elementary context units (ECU) was performed, with an average of three lines, classified according to their vocabularies of higher frequency and higher chi-squared values in the class, in order to understand that they were significant for qualitative data analysis ${ }^{(7-8)}$. The obtained ECUs "have similar vocabulary to each other and different from the ECUs of other classes"(7). The chi-square test is used to verify the association of the ECUs with a particular class; therefore, the higher its value, the greater the association. All selected words had $\mathrm{p}<0.001$, indicating significant association ${ }^{(9)}$. The percentage referring to the content is the "occurrence of the word in the text segments in this class in relation to its occurrence in the corpus" ${ }^{\text {"(10). }}$.

It is noteworthy that this processing in software IRAMUTEQ lasted 59 seconds, which is a significant advantage at this stage in relation to other forms of analysis of qualitative data. The processing obtained 2627 ECUs, with a utilization of $93.8 \%$ of the corpus. After the dimensioning of these ECUs, the classes were then defined, which were presented in the DHC dendogram.

The central elements of each class were analyzed in the light of the five managerial competencies of the theoretical framework $^{(5)}$ for the process of change, and the relationship between classes and managerial competencies was presented by way of a schematic figure containing the center obtained from the classes, involving the managerial competencies and related to the central elements of the textual corpora of each class in boxes.

The study was conducted in accordance with the regulatory guidelines and requirements of Resolution 466/2012 of the National Health Council/MS on Research Involving Human Subjects and approved by the Research Ethics Committee of the University of Paraná, under number 606.957-0. Its viability to the research field at the Municipal Health Department was approved by its Research Ethics Committee. All participants agreed to participate voluntarily in the study by signing the Informed Consent Form.

\section{RESULTS}

The results will be presented in three aspects: characterization of the participating nurses; textual analysis and presentation of classes referring to the process of change experienced by nurses in the FHS expansion, and the relationship between classes and managerial competencies in light of the theoretical framework.

As for the characterization of the participating nurses, only one was male of the 32 participants, and the ages ranged between 31 and 58 years. Their training time was between 5 and 32 years. Among the clinical nurses, the time of work in the HU was lower than a year due to the relocation policy adopted in the county. Regarding the managerial nurses, the predominant time was one to two years in the current job and workplace. The experience with FHS was higher among nursing assistants and the training of managerial nurses in the lato (Specialization/Master's) and stricto sensu (Doctorate) post-graduation courses was higher than assistants.

For textual analysis and presentation of classes referring to the change process, the corpus was divided into two sub-corpus; one sub-corpus corresponding to Class 4, consisting of 790 ECUs, which is a concentration of $32.1 \%$ of the ECUs of the total corpus. The other subcorpus corresponds to class 3 with 497 ECUs, which corresponds to $20.2 \%$ of the ECUs, and two other divisions that originated Class 2 and 1 with 303 and 874 ECUs, respectively, corresponding to $12.2 \%$ in class 2 and $35.5 \%$ in class 1 of the total ECUs, as shown in the Figure 1 dendrogram.

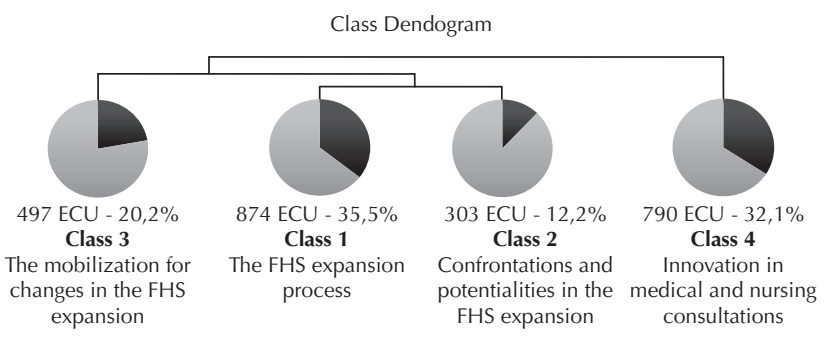

Figure 1 - Class dendogram - The FHS expansion process Curitiba, PR, Brazil, 2014.

Class 1, the FHS expansion process, had the highest number of ECUs as shown in Figure 1. This class revealed aspects related to nurses; and nursing teams' perception and/or experiences working in the FHS expansion process, observed in the following ECUs:

I think that the most significant change, which is
good for the population, is the staff being really
responsible for the population (Gest.15).

I think the nurse has acted as mediator a lot. A mediator among the nursing staff, among the doctor team, among the administration and the staff, most things happen through us (Assist.14).

So we see that they (the users) liked the new professional, that the service is different, the FHS professional has a different vision than the medical clinic... (Assist.5).

In Class 2, corresponding to confrontations and potentialities in the FHS expansion process as seen in Figure 1, ECUs have predominantly evidenced professional remuneration, characteristics and knowledge/ignorance about the FHS, as well as limitations and potentialities of the change process.

So they (the nursing assistants) have no problem with us, but their outrage is the salary issue, 
because FHS professionals earn almost twice as much....(Assist.8).

If the employees themselves do not exactly understand why they are important ... how will they convince people that FHS is best for them? (Gest.15).

(...)But ... they are professionals who believe in public health, collective health, the FHS; they have bought the idea (Gest.8).

Class 3, the mobilization for change, as shown in Figure 1. Meetings were one of the strategies that prevailed to inform and mobilize the $\mathrm{HU}$ team, the population and the Local Council in face of changes to be instituted, and discussed aspects related to management and communication.

(...) many meetings, conversations with the team ... in order to mobilize the community.

There have been several meetings with the Local Council and with participants among users, the community, to explain this process (Gest.5).

Perhaps if we had talked more... about what was going to happen, maybe we could have helped us more and to understand the process better... (Gest.6).

Finally, Class 4, innovation in medical and nursing consultations, shown in Figure 1, demonstrated practices considered innovative by nurses, relating to medical consultations, the valorization of nursing consultations, shared consultations between both professionals and organization of service with expansion of access to population.

So this change of doctors was also very difficult. Only now that we're starting to be able to make sure they understand what their benefit is of being seen by a specialized doctor of the area (Assist.15).

Now it is more comprehensive because for the patient who is in front of me, I have to know what option they have and for me to choose whether I will refer them to a doctor's consultation, or if I'll attend them to solve their case (Assist.4).

(...) so that nurses can really perform their consultations, have the support of doctors and to be resolute in this matter. So much so that there has been an increase in these occurrences/records (Gest.2).

Figure 2 shows the relationship between the classes and the managerial competenciesoutlined in the theoretical reference ${ }^{(5)}$ : implementing and sustaining changes(Class 1 ), negotiating agreements and commitments (Class 2), using power and influence ethically and effectively (Classes 2 and 3), sponsoring and selling new ideas (Class 3), and encouraging and promoting innovation (Class 4); and their key elements defined in the analysis of the textual corpus of the obtained classes.

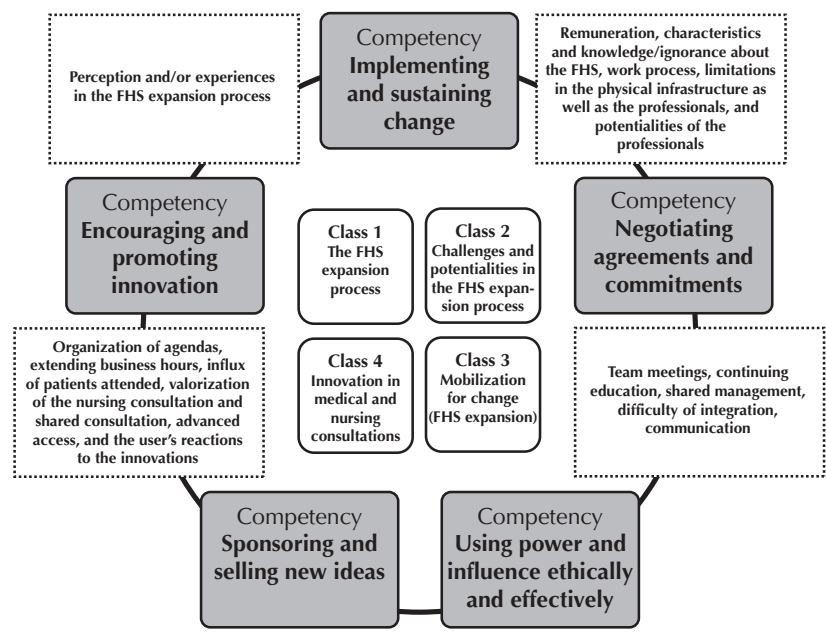

Figure 2-Managerial competencies regarding the FHS expansion process based on the data from the four classes analyzed Curitiba, PR, Brazil, 2014.

\section{DISCUSSION}

With regard to managerial competencies in the change process and its relations with the classes obtained from textual analysis, it can be said that the managerial competencies according to the adopted framework aimed at effectiveness in the change process ${ }^{(5)}$, and in this study, nurses are considered one of the protagonists. As established by the National Primary Care Policy, one of the nurse's responsibilities in $\mathrm{PHC}$ is the management activity of the multidisciplinary team ${ }^{(1)}$.

The managerial competence implementing and sustaining changes is related to Class 1 , which presents the perceptions and experiences of health professionals in the FHS expansion: changes in the labor process, application of PHC principles and guidelines, and financial impact, among other characteristics of the process. Among the advantages, the study participants cited the importance of the reference team and the general professional profile. The FHS enables the implementation of a model of care that meets SUS principles and guidelines, having greater potential for general practitioners becoming familiar and approaching the context of the users. However, a study on the health care of children in HU with and without family health teams identified the need to expand access, longitudinality, integration of care, and other essential attributes for PHC, which is challenging for consolidating the model of care ${ }^{(11)}$.

To succeed in implementing and sustaining changes in the FHS expansion, nurses need to assess what changes are needed and consider the influences that occur in the external environment beyond the context of the HU, such as the political and economic influences, as well as structural and organizational. Considering that external influences can enhance their managerial work, nurses need to be equipped to counteract the external influences that are not aligned to the guidelines and principles of $\mathrm{PHC}$, and consequently, the care model that meets the needs of users. The evaluation of the performed changes must be composed in this process 
in order to support these changes and must be continuously performed for PHC improvement ${ }^{(12)}$.

The managerial competence negotiating agreements and commitments is predominantly related to the results of Class 2. Nurses expressed the need for reorganizing the work process and the confrontations between managers, professionals of health teams and users, requiring negotiations that occurred both during formal and informal meetings. The resulting conflicts between managers and professionals are common in everyday life of HUs, and the second study on the typology of conflicts in a HU may be related to the labor process, professional behavior, infrastructure, etc. ${ }^{(13)}$, which often requires mediation and negotiation. It includes dialogue and consists in solving a problem "through sharing considered points of view"(5). Conflict mediation and negotiation are management tools that support nurses in decision-making processes ${ }^{(14)}$.

The managerial competence using power and influence ethically and effectively is related to the identification of power sources and different tactics that can be used to influence others, as described in Classes 2 and 3. Power exists at an organizational, group or team level and also at an individual or personal level. Although it is most often seen as something negative, its use to mobilize people and resources to achieve institutional goals can be positive ${ }^{(5)}$.

The relocation of professionals for composing family health teams as evidenced in Class 2 affected the structure of a team already formed in the studied HU, as well as a restriction on the possibility of integrating the minimum team of family health and obtaining salary improvements, which led to the coexistence of two teams with different working hours and salaries. Understanding the dimension of change on a personal level and involving reasons and emotions is as necessary as understanding the reasons leading to changes ${ }^{(5)}$.

The mobilization for change, as nurses reported in the ECU Class 3, also provided an opportunity to use power and influence. By analyzing the territory of $\mathrm{HU}$ and how the relations of power exist between managers and health professionals, and/or between them and the users, we must consider conflicts of interests; however, the work must be committed to the health needs of users. In this interaction among all the actors is professional ethics, and knowledge about the relationship between the worker and the user highlight the importance of this work ${ }^{(15-16)}$.

Political fragility can be perceived from the statements of the participants referring to Class 2 and Class 3 and which were related to this competence. By removing the focus on the change process, there is the reflection on power and influence, however, negotiations to achieve agreements rarely succeed if power is used in an authoritarian manner. Some non-controlling strategies were indicated to increase the power and influence on the scope of work, among which are being encouraged to share ideas and recognition for good performance, with these occurring in front of their superiors, which defines the managerial competence sponsoring and selling new ideas, related to Class 3 , through the key elements: meeting, management, and communication ${ }^{(5)}$.
Meetings was the most cited method for communication between the parties involved in the change process, which required significant time on various aspects such as: human resources, composition and responsibilities of the teams, changes in the compensation/salaries, reform in the physical, territorial, and work process structure, among others. Nurses mentioned loopholes in this mobilization for change in claiming that they should have interacted more to understand the proposed changes.

Communication is considered a necessary competence to solve complex health problems ${ }^{(17)}$. To analyze managerial communication, we should consider its four basic types: relational messages to build trust; informative messages to provide the facts; promotional messages to direct action; and transformational messages, used to stimulate change. Transformational messages seek an action ${ }^{(5)}$. Considering the context of SUS, the characterization of its professional training and participatory management, messages considered relational are essential in the communicative process of change.

A literature review on leadership and interpersonal relationships in the health team highlighted the importance of communication in management and that the difficulty of addressing the issue between the team limits their value ${ }^{(18)}$. Thus, it is necessary to improve the organization of health services due to the poor communication between professionals of different levels of care, considering the fragmentation of care provided by each one ${ }^{(19)}$.

The managerial competence encouraging and promoting innovation relates to Class 4 , called innovation in medical and nursing consultations, which the relevant elements of the valorization of nursing, general medical and shared doctor and nurse consultations. Innovation refers to a product, service or improvement that does not necessarily need to be created, but the transposition from one idea to another context is also something innovative ${ }^{(5)}$.

Changes considered innovative by the interviewed nurses related to the consultations that are shared by a family doctor and a nurse, which are intended to expand the access and connectivity of the population with the service and with professionals, and contribute to the care model geared towards comprehensive care and health needs, which is still a challenge for PHC professionals ${ }^{(15)}$. The scheduling of a pre-determined number of medical consultations sought to meet established goals, and nursing visits were not part of the work routine in many HUs, or they were held at restricted numbers. The proposal to meet the demands of the day, and not restricting the number of consultations, lead to the reorganization of professionals' schedulesand the work process ${ }^{(20)}$.

In PHC, nurses are characterized and recognized by understanding the human being as a whole, as well as by providing comprehensive care after welcoming and identifying patients' needs and expectations, both individually and collectively. It integrates different knowledge of professionals, the users and the community, and seeks to optimize care interventions ${ }^{(4)}$. An evaluation of PHC in Spain on the variables which determine the use of the nursing consultation concluded that the criteria for necessity and conditions of accessibility account for the differences in their use, which 
include meeting the user's direct and immediate demands, not only what was pre-scheduled ${ }^{(21)}$.

The incentive for the nursing consultation is related to the deconstruction of centrality in medical consultations. A study on the perceptions of nurses about their work in the FHS points to the practice in the dominant biomedical model, and the challenge of consolidating the shared work of the multidisciplinary team ${ }^{(4)}$. As with what occurs in the matrix support ${ }^{(22)}$, shared consultation between nurses and doctors promotes their integration, exchange and use of knowledge and experience during consultations.

The reported innovations do not exclusively characterize the work in the HU with the FHS, but seek to improve access, connectivity, continuity and resoluteness in care to the population. By reflecting on the care and management of health, and considering the evolution in the transmission of knowledge design and solutions for the production of knowledge by the referenced framework of problematization, professionals are able to propose solutions and innovations ${ }^{(23)}$.

Due to expansion of the FHS, the obtained classes have evidenced that managerial competencies are required as shown in Figure 2, and we can didactically relate each analyzed class to one or two competencies. However, the professional practice reported by participants is complex and dynamic, and does not allow for such segregation. Thus, they are all important and will be more or less used according to the situation experienced by professionals.

\section{CONCLUSION}

The study showed aspects that go beyond exclusive features of the FHS expansion for a broader look at what characterizes PHC. Nursing managerial competencies are related to the process of change, of which does not exclude others outlined in the theoretical framework, as the change does not occur in an isolated way, and therefore different competencies are used concomitantly.

By analyzing the FHS expansion process in the researched scenario and relating it to the managerial competencies of nurses in order to implement the necessary changes, this study can contribute to planning the continued expansion of the FHS and strengthening PHC.

Although the study participants did not mention education as a key point for change, it is reflected in the pursuit of lifelong learning strategies which cannot be overlooked in supporting the process of nursing performance and other health professionals in managing change.

It is recommended that the referenced managerial competencies arising from using the theoretical framework be used in other studies in the health field, in different contexts and for other professionals. The innovative nature of the support from IRAMUTEQ software for data processing in qualitative research in health is also noteworthy because of its recent use in Brazil, while also being an agile tool, facilitating research and providing more consistent and reliable analyses.

\section{RESUMO}

Objetivo: Relacionar as competências gerenciais requeridas dos enfermeiros com o processo de mudança vivenciado na ampliação da Estratégia Saúde da Família. Método: Pesquisa qualitativa realizada na Atenção Primária à Saúde em um município sul brasileiro, por meio de entrevista com 32 enfermeiros gerenciais e assistenciais. As entrevistas foram processadas no software IRAMUTEQ. As classes resultantes foram analisadas à luz de cinco competências gerenciais para promover a mudança. Resultados: As quatro classes que emergiram dos dados foram: o processo de ampliação da Estratégia Saúde da Família; os enfrentamentos e as potencialidades; a mobilização para a mudança; a inovação na consulta médica e na do enfermeiro. As classes foram relacionadas a uma ou mais competências. Conclusão: A ampliação da Estratégia Saúde da Família requer competências gerenciais de implementar e sustentar a mudança, negociar acordos e compromissos, usar o poder e a influência com ética e efetividade, patrocinar e vender novas ideias e estimular e promover inovação.

\section{DESCRITORES}

Enfermagem; Atenção Primária à Saúde; Estratégia Saúde da Família; Competência Profissional; Gerenciamento da Prática Profissional.

\section{RESUMEN}

Objetivo: Relacionar las competencias de gestión requeridas de los enfermeros con el proceso de cambio vivido en la ampliación de la Estrategia Salud de la Familia. Método: Investigación cualitativa realizada en la Atención Primaria a la Salud en un municipio del sur de Brasil, por medio de entrevista con 32 enfermeros de gestión y asistenciales. Las entrevistas fueron procesadas en el software IRAMUTEQ. Las clases resultantes fueron analizadas a la luz de cinco competencias de gestión para promover el cambio. Resultados: Las cuatro clases que emergieron de los datos fueron: el proceso de ampliación de la Estrategia Salude de la Familia: los enfrentamientos y las potencialidades; la movilización para el cambio; y la innovación en la consulta médica y en la del enfermero. Las clases fueron relacionadas con una o más competencias. Conclusión: La ampliación de la Estrategia Salud de la Familia requiere competencias de gestión de implantar y sostener el cambio, negociar acuerdos y compromisos, usar el poder y la influencia con ética y efectividad, patrocinar y vender nuevas ideas y estimular y promover innovación.

\section{DESCRIPTORES}

Enfermería; Atención Primaria de Salud; Estrategia de Salud Familiar; Competencia Profesional; Gestión de la Práctica Profesional.

\section{REFERENCES}

1. Brasil. Ministério da Saúde; Secretaria de Atenção à Saúde, Departamento de Atenção Básica. PNB - Política Nacional de Atenção Básica [Internet]. Brasília; 2012 [citado 2015 fev. 9]. Disponível em: http://189.28.128.100/dab/docs/publicacoes/geral/pnab.pdf 
2. Silva LA, Casotti CA, Chaves SCL. A produção científica brasileira sobre a Estratégia Saúde da Família e a mudança no modelo de atenção. Ciênc Saúde Coletiva [Internet]. 2013 [citado 2013 jul. 9];18(1):221-32. Disponível em: http://www.scielosp.org/pdf/csc/v18n1/23.pdf

3. Massuda A, Poli Neto P, Drehmer VLFG. A atenção primária à saúde (APS) no SUS Curitiba: um desafio para o Brasil, passar de uma APS programática para uma mais acessível e abrangente. In: Sousa MF, Franco MS, Mendonça AVM, organizadores. Saúde da família nos municípios brasileiros: os reflexos dos 20 anos no espelho do futuro. Campinas: Saberes; 2014. p. 127-77.

4. Souza MG, Mandu ENT, Elias AN. Perceptions of nurses regarding their work in the family health strategy. Texto Contexto Enferm [Internet]. 2013 [cited 2015 May 15]; 22(3):772-9. Available from: http://www.scielo.br/pdf/tce/v22n3/en_v22n3a25.pdf

5. Quinn RE, Faerman SR, Thompson MP, Mcgrath MR, Clair LSS. Competências gerenciais: a abordagem de valores concorrentes na gestão. $5^{\mathrm{a}}$ ed. Rio de Janeiro: Elsevier; 2012.

6. Lahlou S. Text mining methods: an answer to Chartier and Meunier. Papers Soc Represent [Internet]. 2012 [cited 2015 Feb 9];20. Available from: http://www.psych.Ise.ac.uk/psr/PSR2011/20_39.pdf

7. Camargo BV, Justo AM. IRAMUTEQ: um software gratuito para análise de dados textuais. Temas Psicol [Internet]. 2013 [citado 2015 fev. 9];21(2):513-18. Disponível em: http://pepsic.bvsalud.org/pdf/tp/v21n2/v21n2a16.pdf

8. Ratinaud P. IRAMUTEQ: Interface de R pour les analyses multidimensionnelles de textes et de questionnaires [computer software]. 2009 [cited 2015 Feb 5]. Available from: http://www.iramuteq.org

9. Chartier JF, Meunier. Text mining methods for social representation analysis in large corpora. Papers Soc Represent [Internet]. 2011 [cited 2015 Feb 5];20. Available from: psych1.Ise.ac.uk/psr/PSR2011/20_38.pdf

10. Camargo BV, Justo AM. Tutorial para uso do software de análise textual IRAMUTEQ. Universidade Federal de Santa Catarina [Internet]. 2013 [citado 2015 fev. 5]. Disponível em: http://www.iramuteq.org/documentation/fichiers/tutoriel-en-portugais

11. Oliveira VBCA, Veríssimo MLÓR. Children's health care assistance according to their families: a comparison between models of Primary Care. Rev Esc Enferm USP [Internet]. 2015 [cited 2015 July 10];49(1):30-6. Available from: http://www.scielo.br/pdf/reeusp/v49n1/00806234-reeusp-49-01-0030.pdf

12. Lancet. Making primary care people-centred: a 21st century blueprint. Lancet. 2014;384(9940):281.

13. Carvalho BG, Peduzzi M, Ayres JRCM. Concepções e tipologia de conflitos entre trabalhadores e gerentes no contexto da atenção básica no Sistema Único de Saúde (SUS). Cad Saúde Pública [Internet]. 2014 [citado 2015 jul. 7];30(7):1453-62. Disponível em: http://www. scielo.br/pdf/csp/v30n7/0102-311X-csp-30-7-1453.pdf

14. Paula M, Peres AM, Bernardino E, Eduardo EA, Macagi STS. Processo de trabalho e competências gerenciais do enfermeiro da estratégia saúde da família. Rev RENE [Internet]. 2013 [citado 2015 jul. 6]:14(4):980-7. Disponível em: http://www.revistarene.ufc.br/revista/index. $\mathrm{php} /$ revista/article/view/1248/pdf

15. Fertonani HP, Pires DEP, Biff D, Scherer MDA. The health care model: concepts and challenges for primary health care in Brazil. Ciênc Saúde Coletiva [Internet]. 2015 [cited 2015 July 10];20(6):1869-78. Available from: http://www.scielo.br/pdf/csc/v20n6/en_1413-8123csc-20-06-1869.pdf

16. Feuerwerker LCM. Micropolítica e saúde: produção do cuidado, gestão e formação. Porto Alegre: Rede Unida; 2014.

17. Olson DK. Competency to collaboration: an interactive process for cross-sectoral development [abstract]. Lancet Global Health. 2014;2 Suppl 1:S39

18. Blanco BM, Valente GSC, Lima CA, Oliveira ACL, Correa MB. The importance of nursing leadership in managing interpersonal relationships among health team. J Res Fundam Care [Internet]. 2013 [cited 2015 July 6];5(3):211-17. Available from: http://www.seer.unirio.br/index. php/cuidadofundamental/article/view/1496

19. Silva SA, Nogueira DA, Paraízo, CMS, Fracolli LA. Assessment of Primary Health Care: health professionals perspective. Rev Esc Enferm USP [Internet]. 2014 [cited 2015 May 15];48(n.spe):126-32. Available from: http://www.scielo.br/pdf/reeusp/v48nspe/0080-6234-reeusp48-esp-126.pdf

20. Knight A, Lembke T. Appointments 101 How to shape a more effective appointment system. Rev AFP [Internet]. 2013 [cited 2015 Apr 22]; 42(3):152-56. Available from: http://www.racgp.org.au/download/Documents/AFP/2013/March/201303 knight.pdf

21. Martín-Fernández J, Rodríguez-Martínez G, Ariza-Cardiel G, Vergel Gutierrez MA, Hedalgo Escudero AV, Conde-López JF. Variables que condicionan la utilización de la consulta de enfermería em centros de salud de la comunidad de Madrid. Rev Esp Salud Publica [Internet]. 2013 [citado 2015 maio. 15]; 87(4):383-92. Disponíble en: http://scielo.isciii.es/pdf/resp/v87n4/08_original_6.pdf

22. Prates MML, Garcia VG, Moreno DMFC. Equipe de apoio e a construção coletiva do trabalho em Saúde Mental junto à Estratégia de Saúde da Família: espaço de discussão e de cuidado. Saúde Soc [Internet]. 2013 [citado 2015 fev. 4];22(2):42-52. Disponível em: http:// www.scielo.br/pdf/sausoc/v22n2/v22n2a31.pdf

23. Falkenberg MB, Mendes TPL, Moraes EP, Souza EM. Educação em saúde e educação na saúde: conceitos e implicações para a saúde coletiva. Ciênc Saúde Coletiva [Internet]. 2014 [citado 2015 jul. 10];19(3):847-52379-401. Disponível em: http://www.scielo.br/pdf/csc/ v19n3/1413-8123-csc-19-03-00847.pdf 